\title{
Role of inositol poly-phosphatases and their targets in T cell biology
}

\author{
Neetu Srivastava ${ }^{1 \dagger}{ }^{+}$, Raki Sudan ${ }^{1 \dagger}$ and William Garrow Kerr ${ }^{1,2,3,4}$ * \\ ${ }^{1}$ Department of Microbiology and Immunology, SUNY Upstate Medical University, Syracuse, NY, USA \\ ${ }^{2}$ Department of Pediatrics, SUNY Upstate Medical University, Syracuse, NY, USA \\ ${ }^{3}$ Department of Biochemistry and Molecular Biology, SUNY Upstate Medical University, Syracuse, NY, USA \\ ${ }^{4}$ Department of Chemistry, Syracuse University, Syracuse, NY, USA
}

Edited by:

Karsten Sauer, The Scripps Research Institute, USA

\section{Reviewed by:}

Klaus Okkenhaug, Babraham Institute, UK

David A. Fruman, University of

California Irvine, USA

\section{*Correspondence.}

William Garrow Kerr, SUNY Upstate Medical University, 750 East Adams Street, 2204 Weiskotten Hall,

Syracuse, NY 13210, USA

e-mail: kerrw@upstate.edu

${ }^{\dagger}$ Neetu Srivastava and Raki Sudan

have contributed equally to this work.
T lymphocytes play a critical role in host defense in all anatomical sites including mucosal surfaces. This not only includes the effector arm of the immune system, but also regulation of immune responses in order to prevent autoimmunity. Genetic targeting of PI3K isoforms suggests that generation of $\mathrm{PI}(3,4,5) \mathrm{P}_{3}$ by PI3K plays a critical role in promoting effector T cell responses. Consequently, the $5^{\prime}$ - and $3^{\prime}$-inositol poly-phosphatases SHIP1, SHIP2, and phosphatase and tensin homolog capable of targeting $\mathrm{PI}(3,4,5) \mathrm{P}_{3}$ are potential genetic determinants of $\mathrm{T}$ cell effector functions in vivo. In addition, the $5^{\prime}$-inositol poly-phosphatases SHIP1 and 2 can shunt $\mathrm{PI}(3,4,5) \mathrm{P}_{3}$ to the rare but potent signaling phosphoinositide species PI $(3,4) \mathrm{P}_{2}$ and thus these SHIP1/2, and the INPP4A/B enzymes that deplete $\mathrm{PI}(3,4) \mathrm{P}_{2}$ may have precise roles in T cell biology to amplify or inhibit effectors of PI3K signaling that are selectively recruited to and activated by $\mathrm{PI}(3,4) \mathrm{P}_{2}$. Here we summarize recent genetic and chemical evidence that indicates the inositol poly-phosphatases have important roles in both the effector and regulatory functions of the T cell compartment. In addition, we will discuss future genetic studies that might be undertaken to further elaborate the role of these enzymes in T cell biology as well as potential pharmaceutical manipulation of these enzymes for therapeutic purposes in disease settings where $T$ cell function is a key in vivo target.

Keywords: SHIP1, SHIP2, T cells, T lymphocytes, adoptive T cell transfer, INPP4, PTEN, PI3K

\section{INTRODUCTION}

Inositol phospholipid signaling pathway plays an integral role in development, proliferation, differentiation, and survival of lymphocytes (1-4). The principal second messenger of the PI3K pathway $\operatorname{Ptd} \operatorname{Ins}(3,4,5) \mathrm{P}_{3}$ is generated by phosphorylation of the $3^{\prime}$ hydroxyl group of PtdIns $(4,5) \mathrm{P}_{2}$ by PI3Ks. PI3Ks are grouped into three categories, Class I, II, and III on the basis of substrate specificity and structure. Only class I PI3Ks can use $\operatorname{PtdIns}(4,5) \mathrm{P}_{2}$ to generate PtdIns $(3,4,5) \mathrm{P}_{3}$ at the inner leaflet of plasma membrane (5). $\operatorname{PtdIns}(3,4,5) \mathrm{P}_{3}$ acts as binding site for several intracellular signaling molecules that containing a Pleckstrin-homology domain ( $\mathrm{PH}$-domain) and thus facilitates their recruitment to the plasma membrane. AKT/PKB is the most important $\mathrm{PH}$-domain containing kinase required for cell growth, survival, and proliferation in most cell types and appropriately its $\mathrm{PH}$-domain can bind PtdIns $(3,4,5) \mathrm{P}_{3}(6,7)$. In addition to AKT, the PH-domain containing Tec family tyrosine kinases ITK (IL-2-inducible T cell kinase) and BTK (Bruton agammaglobulinemia tyrosine kinase) also have specificity for $\operatorname{PtdIns}(3,4,5) \mathrm{P}_{3}$ and are important mediators of PI3K signaling pathway in T and B cells, respectively

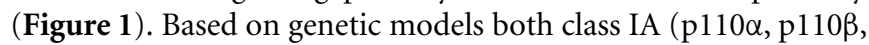
and $\mathrm{p} 110 \delta)$ and class IB PI3K (p110 $\gamma)$ play roles in thymocyte development. p110 $\gamma$-knockout mice have increased apoptosis of DP thymocytes and double knockout $\mathrm{p} 110 \delta / \gamma$ mice have significantly reduced number of thymocytes, a profound $\mathrm{T}$ cell lymphopenia and multiple organ inflammation (8-12). In addition to that mice with a knock-in point mutation of p1108 (p110deltaD910A/D910A) have severe defects in T cell receptor signaling and impaired Treg cell function (13-15). The T cell specific class IA PI3K deficient mice do not have defects in thymocyte and in peripheral $\mathrm{T}$ cell development, but they do exhibit defective TCR signaling, in vitro proliferation and cytokine production (16, 17). Altogether these findings demonstrate that the PI3K signaling pathway responsible for generation of $\operatorname{Ptd} \operatorname{Ins}(3,4,5) \mathrm{P}_{3}$ plays an important role in $\mathrm{T}$ cell development and activation and suggest that inositol poly-phosphatases like phosphatase and tensin homolog (PTEN), SHIP1, SHIP2, and INPP4A/B may have an opposing, or in some cases, a facilitating role downstream of PI3K in T lymphocytes.

The cellular pool of inositol phospholipids is determined in part by inositol phosphatases that by dephosphorylation of $\operatorname{PtdIns}(3,4,5) \mathrm{P}_{3}$, can regulate PI3K-mediated signaling pathway. Three important phosphatases, which dephosphorylate PtdIns $(3,4,5) \mathrm{P}_{3}$ are PTEN, SHIP1, and SHIP2. PTEN is $3^{\prime}$ polyphosphatase that converts $\operatorname{PtdIns}(3,4,5) \mathrm{P}_{3}$ to $\operatorname{PtdIns}(4,5) \mathrm{P}_{2}$ while the SHIP family phosphatases, SHIP1 and SHIP2, are $5^{\prime}$ polyphosphatases, which convert $\operatorname{PtdIns}(3,4,5) \mathrm{P}_{3}$ to $\operatorname{PtdIns}(3,4,) \mathrm{P}_{2}$ $(18,19)$. The importance of these phosphatases in immune cell signaling was revealed by the demonstration that SHIP1 deficiency leads to severe myeloproliferative disorder and impaired NK cell 


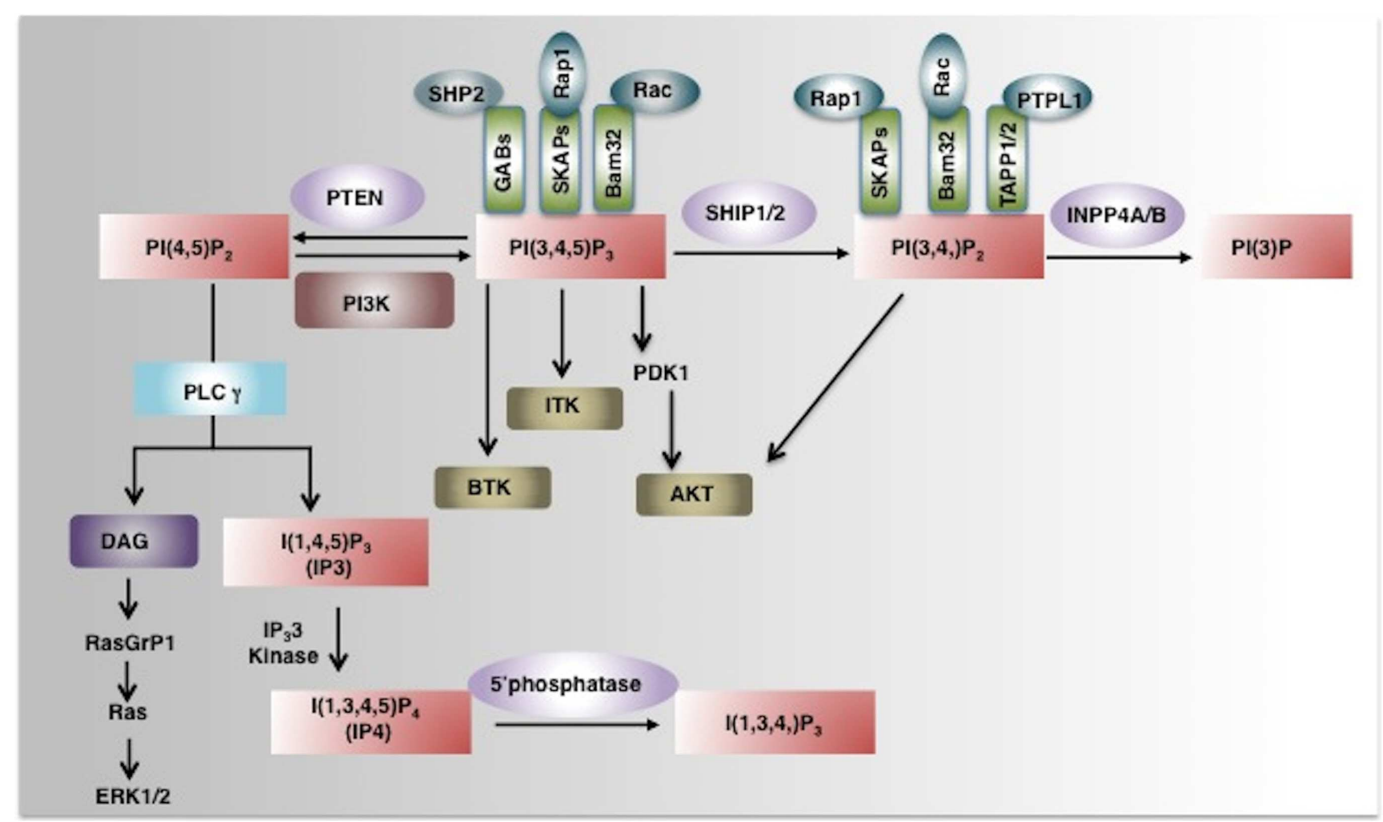

\section{FIGURE 1 | Phosphoinositide signaling and its regulation by} phosphatases. $\mathrm{PI} 3 \mathrm{~K}$ converts $\mathrm{PI}(4,5) \mathrm{P}_{2}$ to a key secondary messenger $\mathrm{PI}(3,4,5) \mathrm{P}_{3}$. Phosphatases like PTEN and SHIP1/2 regulate cellular levels of $\mathrm{PI}(3,4,5) \mathrm{P}_{3}$ by hydrolyzing it to $\mathrm{PI}(4,5) \mathrm{P}_{2}$ and $\mathrm{PI}(3,4) \mathrm{P}_{2}$ respectively. PLC $\gamma$ converts $\mathrm{PI}(4,5) \mathrm{P}_{2}$ to $\mathrm{IP}_{3}$ and DAG. IP 3 a soluble inositol phosphate is required for $\mathrm{Ca}^{2+}$ mobilization while DAG can activate the Ras-Raf-ERK1/2 pathway. $I \mathrm{P}_{3}$ 3-Kinases convert $I \mathrm{P}_{3}$ to $\mathrm{IP}_{4}$, another important soluble inositol poly-phosphate that either positively or negatively regulates the binding of $\mathrm{PI}(3,4,5) \mathrm{P}_{3}$ to $\mathrm{PH}$-domain containing proteins. The SHIP1/2 product PI(3,4)P2 is hydrolyzed by INPP4A/B into
$\mathrm{PI}(3) \mathrm{P}$ by removal of the phosphate at the 4-position of the inositol ring. $\mathrm{PI}(3,4,5) \mathrm{P}_{3}$ and/or $\mathrm{PI}(3,4) \mathrm{P}_{2}$ enable recruitment to the plasma membrane of several PH-domain containing proteins including PDK1, AKT, BTK, ITK, and thus regulate pivotal cellular processes including activation, proliferation, and survival. $\mathrm{PH}$-domain containing adaptor proteins (GABs, SKAPs, Bam32, and TAPP) can also bind to phosphoinositides and regulate cell signaling (indicated as green boxes). AKT, Protein Kinase $B$; PDK1, phosphoinositide-dependent kinase-1, PLC $\gamma$ phospholipase $\mathrm{C} \gamma$; ITK, IL-2-inducible T cell kinase) and BTK, Bruton agammaglobulinemia tyrosine kinase. function while mice with a conditional deletion of PTEN have impaired $\mathrm{T}$ cell immune responses (20-22). The present review focuses on the role of these inositol phosphatases in $\mathrm{T}$ cell biology.

\section{SHIP1 IN T CELL BIOLOGY}

SHIP1 (Src homology 2-containing inositol phosphatase) is a $5^{\prime}$ inositol poly-phosphatase that removes the $5^{\prime}$ phosphate from PtdIns $(3,4,5) \mathrm{P}_{3}$ and $\operatorname{Ins}(1,3,4,5) \mathrm{P}_{4}$, thereby regulating $\mathrm{PI} 3 \mathrm{~K}$ signaling pathway (23). SHIP1 is expressed in hematopoietic cells, mesenchymal stem cells, and osteoblasts (24) as a $145 / 150 \mathrm{kDa}$ doublet. SHIP1 contains an N-terminal SH2 domain, a central phosphatase domain, a C-terminal NPXY motifs, a Serine residue that can be phosphorylated by PKA, proline rich sequences as well as domains adjacent to the phosphatase domain that can recognize either its substrate or its product (23). The SH2 domain mediates binding of SHIP1 to ITAM and ITIM motifs in receptor tails such as the CD3 chains that associate with the TCR $(25,26)$ or with various adaptor proteins $(27,28)$. By virtue of its enzymatic as well as its non-enzymatic functions, SHIP1 is implicated in various signaling pathways related to proliferation, apoptosis, cytokine signaling in lymphocytes and myeloid cells (23). Germline SHIP1 ${ }^{-1-}$ mice although viable after weaning develop profound infiltration of myeloid cells in the lungs and severe inflammation in the terminal ileum of the gut resembling human Crohn's disease (29) which leads to their early demise $(20,30)$. SHIP $1^{-/-}$mice have increased number of myeloid cells in most of tissues, but are lymphopenic (20) and have a profound deficit of T cells in the gut (29) indicating diverse functions for SHIP1 signaling in myeloid cells and $\mathrm{T}$ lymphocytes.

\section{SHIP1 IN T CELL SIGNALING}

First demonstration of involvement SHIP1 in T cells came from the observation that ligation of CD3 or CD28 on T cells results in SHIP1 tyrosine phosphorylation and membrane re-localization (31). SHIP1 is thought to be a component of a signaling complex that includes LAT (linker for activation of T cells), Grb2, Dok (downstream of tyrosine kinase) 1, and Dok2 that negatively regulate TCR signaling (32). SHIP1 functions as an adaptor that is required for tyrosine phosphorylation of Dok1 and Dok2 and thus enables Dok1/2 anchoring to LAT to negatively regulate the Zap-70 and AKT kinases thus attenuating TCR signaling (32). Consistent with the proposed negative regulation of TCR signaling, SHIP1 together with adaptor Dok1 and Dok2 has also been shown to be associated with the CD4-mediated inhibitory signaling (33). SHIP1 can also negatively regulate activation and membrane localization of Tec Kinase, which plays an essential role in PLC $\gamma$ activation upon TCR stimulation $(34,35)$. However, despite these biochemical studies suggesting SHIP1 limits TCR signaling splenic T cells isolated from germline $\mathrm{SHIP} 1^{-} /^{-}$mice have defective TCR signaling as shown by their poor proliferation in response 
to TCR stimulation. In addition, SHIP1 ${ }^{-1-} \mathrm{T}$ cells fail to induce IL-2 and IFN $\gamma$ upon PMA/ionomycin stimulation although they have elevated levels of CD69 and CD25 and dramatically reduced expression CD62L and CD45RB expression (36). However a T cellrestrictive deletion of SHIP1 (CD4CreSHIP ${ }^{\Delta \text { IPflox }) ~ t h a t ~ d e l e t e s ~}$ SHIP1 at double positive thymocyte stage does not exhibit the same T cell phenotype observed in the germline SHIP $1^{-} /^{-}$mice (37). SHIP1 deleted T cells in these mice do not regulate TCR signal strength and no difference in the phosphorylation status of AKT, ERK, Zap-70, PLC $\gamma$, or calcium influx was observed between SHIP1 ${ }^{-} /^{-}$and WT T cells. Also, in contrast to the poor proliferation of $\mathrm{T}$ cells from germline deficient mice, $\mathrm{T}$ cells from CD4CreSHIP ${ }^{\Delta \text { IPflox }}$ mice proliferate normally in response to TCR stimulation. The authors argued that the observed phenotype of $\mathrm{T}$ cells in germline SHIP1 $1^{-} /^{-}$mice is due to pleiotropic effect of dysregulated immune system as a consequence of SHIP1-deficient environment $(37,38)$. However, we and others have found that the in-frame deletion strategy utilized still allows substantial expression of a near full-length version of SHIP1 that only lacks the enzyme domain (39). Because of SHIP1's ability to function in cell signaling by masking binding sites on receptor tails for other regulatory kinases and phosphatases $(40,41)$ confounds interpretation of results from $\mathrm{SHIP}^{\Delta \text { IPflox }}$ strain difficult.

\section{SHIP1 IN T CELL DEVELOPMENT}

SHIP1 alone does not affect T cell development as no deficiencies in the development of T cells in the thymus was observed in either germline SHIP $1^{-} /^{-}$deficient mice or in CD4CreSHIP ${ }^{\Delta \text { IPflox }}$ mice (20, 36, 37). However, a double knockout of SHIP1 and adaptor protein Dok1 plays an important role in T cell development since mice with combined deficiency of SHIP1 and Dok1 have significantly reduced total thymocyte numbers, percentage of $\mathrm{CD} 4^{+}$ $\mathrm{CD}^{+}$double positive $\mathrm{T}$ cells and increased $\mathrm{CD} 4^{-} \mathrm{CD} 8^{-}$double negative T cells (36).

SHIP1 has been shown to be required for both $\mathrm{CD} 4^{+}$and $\mathrm{CD} 8^{+}$ T cell survival homeostasis at mucosal sites $(29,42)$. SHIP1 ${ }^{-}{ }^{-}$ mice develop spontaneous intestinal inflammation, the disease is highly demarcated and confined to the terminal ileum, which resembles classical human Crohn's disease (29). The disease is characterized by severe reduction in $\mathrm{CD}^{+}$and $\mathrm{CD}^{+}{ }^{+} \mathrm{T}$ cells in the lamina propria of SHIP1 $1^{-/-}$mice suggesting that SHIP1 is required for effector $\mathrm{T}$ cell persistence in the small intestine. Because $\mathrm{T}$ cells play an important role in normal immune surveillance to both commensal microorganism and pathogens, in their absence SHIP1-deficient Neutrophils and other myeloid cells over-respond resulting in lethal inflammation in SHIP1-/mice (29). The mechanism of selective loss of T cells in mucosal tissues is currently under investigation. T cell-restrictive SHIP1deficient CD4CreSHIP ${ }^{\Delta \text { IPflox }}$ reported by Tarasenko et al. have apparently no defect in $\mathrm{T}$ cell activation or $\mathrm{T}$ cell numbers in periphery; however, mucosal $\mathrm{T}$ cells were not examined in their report (37). Interestingly $\mathrm{T}$ cells from CD4CreSHIP ${ }^{\Delta \mathrm{IPflox}}$ mice show biased toward Th1 skewing and have defective production of Th2 cytokines IL-4, IL-5, and IL-13. Consistent with this T cells from CD4CreSHIP ${ }^{\triangle \text { IPflox }}$ mice respond poorly to in vivo challenge to Schistosoma mansoni eggs, which normally induce a Th2 response. These cells also express elevated levels of T-bet which has been shown to regulate CD8 T cell function. Consistent with that CD8 T cells from CD4CreSHIP ${ }^{\Delta \text { IPflox }}$ mice that also delete SHIP1 in CD8 T cells were more efficient in a cytotoxicity assay as compared to WT controls (37).

\section{REGULATION OF Tregs AND TH17 CELLS BY SHIP1}

SHIP1 has been shown to limit expansion both myeloid and $\mathrm{T}$ lymphoid immune-regulatory cell $(30,36,43-46)$. Peripheral T cells from SHIP1 ${ }^{-1-}$ mice have significantly increased numbers of $\mathrm{CD} 4{ }^{+} \mathrm{CD} 25^{+} \mathrm{FoxP}^{+}$conventional regulatory $\mathrm{T}$ cells $(36,45)$. They exhibit significantly higher levels of CD103, GITR, OX40, and FcR $\gamma \mathrm{II} / \mathrm{III}$, which is associated with their regulatory function (45). SHIP $1^{-1-}$ regulatory $\mathrm{T}$ cells are equally suppressive both in vitro and in vivo when compared to SHIP1-competent $\mathrm{T}$ regulatory cells (45). In addition to conventional regulatory $\mathrm{T}$ cells, SHIP1 deficiency also promotes the accumulation of $\mathrm{CD} 4{ }^{+} \mathrm{CD} 25^{-}$iTreg cells that express FoxP3 in the periphery that have suppressive function (45). Although SHIP1 deficiency seems to promote regulatory $\mathrm{T}$ cell expansion, the inflammatory environment brought about by SHIP1-deficient myeloid cells may also play a role in Treg cell development. An elegant study by Collazo et al. demonstrated that SHIP1 regulates Treg cell development and iTreg formation in both a $\mathrm{T}$ cell intrinsic and extrinsic manner. Both T cell specific deletion of SHIP1 in LckCreSHIP flox/flox or myeloid cell-specific deletion in LysCreSHIP flox/flox mice increased the peripheral pool of $\mathrm{CD} 4{ }^{+} \mathrm{CD} 25^{+}$FoxP $3^{+}$regulatory $\mathrm{T}$ cells and $\mathrm{CD} 4{ }^{+} \mathrm{CD} 25^{-}$iTreg cells expressing FoxP3 (44). These results indicate that SHIP1 exerts both $\mathrm{T}$ cell intrinsic and extrinsic control over peripheral Treg cell development and conversion in the periphery. In contrast to this, Tarasenko et al. in the

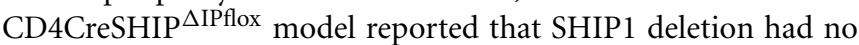
effect on Treg cell development. However, the concern noted above regarding residual expression of a near full-length SHIP1 mutant in SHIP ${ }^{\Delta \text { IPflox }}$ mice hampers interpretation of this negative finding. Locke et al. also reported $\mathrm{T}$ cell-intrinsic function of SHIP1 in iTreg development. They showed that the ability of SHIP $1^{-/-} \mathrm{CD} 4^{+} \mathrm{CD} 25^{-} \mathrm{CD} 45 \mathrm{RB}^{\text {high }} \mathrm{T}$ cells to develop into Foxp $3^{+}$cells in vitro in presence of TGF $\beta$ alone or in combination with retinoic acid (RA) was much higher compared to WT $\mathrm{T}$ cells (47). Interestingly, FoxP3 can enhance the expression of miR-155 by binding to an intron within the DNA sequence of the miR-155 precursor RNA suggesting that FoxP3 could potentially maintain Treg numbers by suppressing SHIP1 expression through induction of miR-155 (48-50). Altogether the above studies suggest a potent role for SHIP1 in T cell-intrinsic control of native Treg development and iTreg formation in the periphery. In contrast to SHIP1's function in limiting Treg numbers, it has been shown to required for Th17 development. SHIP $1^{-1-} \mathrm{T}$ cells fail to differentiate into Th17 cells and this deficiency was accompanied by reduced IL- 6 mediated phosphorylation STAT3 (47). SHIP $1^{-1-}$ T cells have high basal level of T-bet, a transcription factor known to negatively regulate Th17 differentiation and lower levels of ROR $\gamma \mathrm{t}$ mRNA, and thus it is likely that the altered $\mathrm{T}$ cell differentiation are regulated by SHIP1 via its control of these transcription factors at the molecular level. Table 1 summarizes the function SHIP1 in T cells in different genetic mouse models. 
Table 1 | T cell phenotypes of inositol poly-phosphatase mutant mice.

\begin{tabular}{|c|c|c|c|c|}
\hline No. & KO & Gene deletion & T cell phenotype & Reference \\
\hline 1 & $\mathrm{SHIP}^{-/-}$ & Germline SHIP1 deletion & $\begin{array}{l}\text { Poor proliferation of T cells } \\
\text { Elevated levels of CD } 69, \mathrm{CD} 25 \text { on T cells, and reduced } \\
\text { levels of CD69L, CD45RB } \\
\text { Increased CD4 }{ }^{+} \mathrm{CD} 25^{+} \text {FoxP3 }^{+} \text {Tregs } \\
\text { Increased CD4 }{ }^{+} \mathrm{CD} 25^{-} \text {FoxP3 }{ }^{+} \text {iTregs } \\
\text { Reduced } \mathrm{CD} 4^{+} \text {and } \mathrm{CD} 8^{+} \text {T cells in the gut }\end{array}$ & $\begin{array}{l}\text { Helgason et al. (20), Kerr } \\
\text { et al. (29), Kashiwada et } \\
\text { al. (36), Collazo et al.(45) }\end{array}$ \\
\hline 2 & SHIP-/-DOK1-/- & Germline SHIP1 and DOK1 deletion & $\begin{array}{l}\text { Reduced thymocytes } \\
\text { Reduced CD+CD8+ T cells in thymus } \\
\text { Reduced } C D 8^{+} \mathrm{T} \text { cells in the spleen } \\
\text { Altered CD4:CD8 ratio } \\
\text { Increased CD4+ }{ }^{+} \text {CD } 25^{+} \text {FoxP3 }{ }^{+} \text {Tregs }\end{array}$ & Kashiwada et al. (36) \\
\hline 3 & CD4CreSHIPf/f & SHIP1 deletion in T cells & $\begin{array}{l}\text { Normal T cell development } \\
\text { No defect in T cell activation } \\
\text { Reduced levels of TH2 cytokines IL-4, IL-5, and IL-13 } \\
\text { CD8 }+ \text { T cells are more cytotoxic }\end{array}$ & Tarasenko et al. (37) \\
\hline 4 & LckCreSHIPf/f & SHIP1 deletion in T cells & 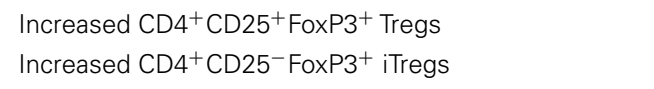 & Collazo et al. (44) \\
\hline 5 & LysCreSHIPf/f & SHIP1 deletion in myeloid cells & $\begin{array}{l}\text { Increased } \mathrm{CD} 4^{+} \mathrm{CD}_{25}{ }^{+} \mathrm{FoxP}^{+} \text {Tregs } \\
\text { Increased } \mathrm{CD} 4^{+} \mathrm{CD} 25^{-} \text {FoxP3 }^{+} \text {iTregs }\end{array}$ & Collazo et al. (44) \\
\hline 6 & PTEN $^{-1+}$ & Heterozygous deletion of PTEN & $\begin{array}{l}\text { Increased proliferation of T cells } \\
\text { Reduced AICD }\end{array}$ & Di Cristofano et al. (51) \\
\hline 7 & LckCre-PTEN ${ }^{\text {flox/- }}$ & $\begin{array}{l}\text { PTEN deletion in T cells/heterozygous } \\
\text { deletion of PTEN other tissues }\end{array}$ & $\begin{array}{l}\text { CD4 }+ \text { T cell lymphoma } \\
\text { Defect in thymic negative selection } \\
\text { Increased } \mathrm{TH} 1 / \mathrm{TH} 2 \text { cytokines } \\
\text { T cells are resistant to apoptosis }\end{array}$ & Suzuki et al. (22) \\
\hline 8 & LckCre-PTEN $^{f / f}$ & PTEN deletion in T cells & $\begin{array}{l}\text { T cells are hyper-responsive to TCR stimulation } \\
\text { Refracted to anergy induction } \\
\text { Reduced expansion of Tregs } \\
\text { Increased TH2 cytokine }\end{array}$ & $\begin{array}{l}\text { Hagenbeek et al.(52), } \\
\text { Walsh et al.(53) }\end{array}$ \\
\hline 9 & OX40 ${ }^{\text {cre }}$ PTEN ${ }^{f l o x}$ & PTEN deletion in mature $\mathrm{CD}^{+}{ }^{+} \mathrm{T}$ cells & $\begin{array}{l}\text { T cells are hyper-proliferative } \\
\text { Secrete more cytokine } \\
\text { T cells are super-helper with enhanced inflammatory } \\
\text { antibacterial and anti-tumor responses }\end{array}$ & Soond et al. (54) \\
\hline
\end{tabular}

\section{SHIP1 IN T CELL MIGRATION}

PI3K-associated pathways have been implicated in regulation of chemokine signaling and migration of cell toward chemokine gradient $(55,56)$. In a polarized plasma membrane PI3K accumulates at the leading edge of the migratory cells leading to localized production of $\mathrm{PI}(3,4,5) \mathrm{P}_{3}$ and thereby regulating cell migration. Because SHIP1 regulates levels of $\mathrm{PI}(3,4,5) \mathrm{P}_{3}$ at PI3K signaling complexes it stands to reason that it may then regulate chemotaxis. Nishio et al. demonstrated that SHIP1-deficient neutrophils fail to polarize $\mathrm{PI}(3,4,5) \mathrm{P}_{3}$ at the leading edge of migrating cells resulting in the inefficient migration of neutrophils and reduced polarity in response to chemoattractants (57). In T cells enhanced chemotaxis in response to stromal cell-derived factor-1 (SDF1) has been reported with SHIP1 ${ }^{-1-}$ thymocytes and splenic $\mathrm{CD}^{+}$ $T$ cells (58). Consistent with this enforced overexpression of SHIP1 in Jurkat T cells abrogated CXCL12 mediated chemotaxis by this cell line (59). However it was also shown that the chemotaxis of SHIP $1^{-1-}$ lymphocytes with other chemokines was comparable with that of WT lymphocytes indicating that SHIP1 involvement in regulating chemotaxis may be chemokine specific (58). More recently Harris et al. by using a lentivirally expressed SHIP1specific shRNA in human $\mathrm{CD}^{+}{ }^{+} \mathrm{T}$ cells showed that although the directional chemotaxis toward CXCL11 was unaffected, the overall basic motility and morphology of $\mathrm{T}$ cells was impaired in SHIP1 knockdown (KD) primary human T cells (60). SHIP1 KD T cells exhibited increased actin polymerization and loss of microvilli projection upon stimulation with CXCL11. Formation of microvilli involves phosphorylation of ezrin/radixin/moesin (ERM) proteins and once the cell is activated microvilli are frequently lost due to Rac-mediated dephosphorylation of ERM 
proteins (61). SHIP1 seems to negatively regulate Rac activation and/or ERM phosphorylation through a non-catalytic function as pretreatment with the PI3K inhibitor Ly294002 fails to rescue microvilli disassembly (60). However, a partial rescue in ERM phosphorylation by a Rac inhibitor in SHIP1 KD T cells indicates that Rac independent pathways are also involved. Additionally, the $\mathrm{PH}$-domain containing adaptor protein Bam32, that can bind to both $\mathrm{PI}(3,4,5) \mathrm{P}_{3}$ and $\mathrm{PI}(3,4) \mathrm{P}_{2}$, the SHIP1 substrate and product, respectively, is required for Racl activation and efficient BCRinduced cell adhesion (62). Thus, it is possible that both SHIP1 catalytic and non-catalytic functions are required for chemotaxis and cytoskeletal rearrangement; however, mechanistic studies in $\mathrm{T}$ cell conditional SHIP1 mutants are required to better define specific functions of SHIP1 in regulating these processes in an in vivo setting.

\section{SHIP1 IN T CELL APOPTOSIS}

The PI3K pathway is largely associated with cellular survival and proliferation as its product $\mathrm{PI}(3,4,5) \mathrm{P}_{3}$ is known to activate molecules required for cell survival and proliferation. Because SHIP1 degrades $\mathrm{PI}(3,4,5) \mathrm{P}_{3}$, it is primarily considered a negative regulator of PI3K-mediated cell survival. Indeed, SHIP1 plays a proapoptotic function in myeloid, erythroid, and in some instances B cells (63-66). However, it appears to play an opposite function in T cells. For instance SHIP1 limits Fas-induced apoptosis in human primary T cells ex vivo and a leukemic T cell line (67). Jurkat T cells, which do not express SHIP1 at normal levels are very sensitive to FasL mediated apoptosis; however, when SHIP1 is over-expressed in Jurkat T cells they become resistant to $\mathrm{H}_{2} \mathrm{O}_{2}$ and FasL mediated apoptosis $(67,68)$. It is also reported that SHIP1 attenuates Fc $\gamma$ RIIB mediated apoptosis in B cells and that the failure to recruit SHIP1 to the receptor results in enhanced apoptosis $(69,70)$. Importantly SHIP $1^{-1-}$ mice are lymphopenic, and have profound deficiency of both $\mathrm{CD}^{+}{ }^{+}$and $\mathrm{CD} 8^{+} \mathrm{T}$ cells in the gut indicating that SHIP1 might be required for $\mathrm{T}$ cell survival (20, 29). A selective deficiency of effector $T$ cells at these sites might result in recruitment of myeloid cells, which subsequently leads to the lethal mucosal inflammation in both the lungs and gut of SHIP $1^{-1-}$ mice $(23,29)$. Interestingly reconstitution of sublethally irradiated SHIP1 $1^{-/-}$mice with SHIP1-competent T cell graft protects them from mucosal inflammation and prolongs their survival. Moreover, SHIP1 is required for persistence of mature T cells in the periphery and at mucosal surfaces as SHIP $1^{-1-}$ T cells are impaired for survival when forced to compete with SHIP $1^{+/+}$ $\mathrm{T}$ cells for representation in the peripheral $\mathrm{T}$ cell pool of either immunocompetent or SCID hosts. Our preliminary studies indicate that SHIP1 mediated protection of T cell death at mucosal surfaces involves Fas-FasL death receptor pathway (42). Unlike myeloid cells in which SHIP1 appears to promote cell death, T cells require SHIP1 for their survival and persistence. A growing body of evidence implicates $\mathrm{PI}(3,4) \mathrm{P}_{2}$, the SHIP1 product, in cell survival as it can more efficiently recruit and activate $\operatorname{Akt}(71,72)$ and protects cancer cells from apoptosis induced by SHIP1 selective (43) and pan-SHIP1/2 inhibitors (73). Consistent with this role of $\mathrm{PI}(3,4) \mathrm{P}_{2}$ and SHIP1/2 in promoting cell survival, increased levels of $\mathrm{PI}(3,4) \mathrm{P}_{2}$ in INPP4A and INPP4B mutant mice promote cell transformation and tumorigenicity $(74,75)$. SHIP1 and SHIP2 should not only be considered terminators of PI3K-mediated survival pathway, but paradoxically also facilitators of such survival signaling. With the growing evidence of its anti-apoptotic role in $\mathrm{T}$ cells, and in various cancer cells, it is important to understand when and how SHIP1 promotes pro-apoptotic vs. anti-apoptotic signaling. Here both cell types and the involved receptor(s) are likely critical determinants of this positive vs. negative role for SHIP1 and SHIP2 in apoptosis.

\section{SHIP1 AND PHOSPHOINOSITIDE-BINDING PH-DOMAIN CONTAINING ADAPTOR PROTEINS}

SHIP1's role as a positive regulator of PI3K signaling pathway can also be attributed to the ability of $\mathrm{PI}(3,4) \mathrm{P}_{2}$, the SHIP1 product to mediate recruitment of $\mathrm{PH}$-domain containing adaptor proteins including SKAP adaptors (SKAP55 and SKAP-hom), Bam32 (also known as DAPP1), TAPP1, and TAPP2 (76). These adaptor proteins have differential ability to bind phosphoinositides, $\mathrm{PI}(3,4,5) \mathrm{P}_{3}$ vs. $\mathrm{PI}(3,4) \mathrm{P}_{2}$ (Figure 1) and also exhibit differential expression across immune cell types. For instance SKAP55 expression is relatively more restricted to T cells while SKAP-hom is more widely expressed in immune cells. Although Bam32 is restricted to hematopoietic cells, it is more abundant in B cells and expressed in lower levels in T cells, dendritic cells, and macrophages. TAPP proteins are widely expressed in all the tissues; however TAPP2 is more abundant in immune cells (76). TAPP1 and TAPP2 stand out among the adaptor proteins as they can only bind to $\mathrm{PI}(3,4) \mathrm{P}_{2}(27$, 77), while SKAP adaptors and Bam 32 can bind to both $\mathrm{PI}(3,4,5) \mathrm{P}_{3}$ vs. $\mathrm{PI}(3,4) \mathrm{P}_{2}$ with equal affinity $(76)$. Mice deficient in SKAP55, which predominantly functions in T cells have impaired TCR induced adhesion to integrin ligands suggesting a role of SKAP in PI3K-mediated integrin activation in lymphocytes (78). Bam32 has been implicated in BCR signaling of B cells as Bam $32^{-1-}$ mice have defects in various aspects of $\mathrm{B}$ cell activation. Bam $32^{-1-} \mathrm{B}$ cells have impaired BCR-induced proliferation and defective Tindependent antibody responses (62). Bam32 has also shown to be required for germinal center progression and antibody affinity maturation (79). Bam $32^{-1-}$ B cells are defective in cell spreading presumably due impaired cytoskeleton rearrangement (76). In $\mathrm{T}$ cells Bam32 is required for TCR mediated ERK activation (80, 81). Thus, SHIP1 through hydrolysis of $\mathrm{PI}(3,4,5) \mathrm{P} 3$ to $\mathrm{PI}(3,4) \mathrm{P}_{2}$ could differentially regulate the recruitment of SKAP and Bam32 adaptors and thereby impact $\mathrm{T}$ cell signaling. This question merits further study in SHIP mutant T cells and in the mice mutants for these adaptor proteins.

SHIP1 has been shown to enhance membrane recruitment of TAPP1 and TAPP2, the only adaptor proteins known to exclusively bind $\mathrm{PI}(3,4) \mathrm{P}_{2}(82)$. Recently a knock-in mouse model that express normal endogenous level of mutant TAPP1 and TAPP2 which are incapable of binding to $\mathrm{PI}(3,4) \mathrm{P}_{3}$ has been made to understand their physiological functions (83). Interestingly, the defects observed in the B cells of TAPP KI mice showed remarkable similarities with that of SHIP1 $1^{-/-}$mice (84). TAPP KI mice have elevated levels of serum immunoglobulin, autoantibody production, and they show a lupus-like phenotype. Importantly AKT phosphorylation was significantly increased upon BCR cross linking in B cells purified from these mice enhancing their proliferation (84). This indicates that in the absence of TAPP adaptor proteins, the 
$\mathrm{PI}(3,4) \mathrm{P}_{2}$ is available to promote AKT recruitment and resulting in increased proliferation and survival, consistent with the proposed positive function of SHIP1 in survival and proliferation (23). The precise role(s) of TAPP as adaptor proteins in T cells is relatively uncharacterized; however, TAPP can bind to PTPL1 which, has been shown to inhibit cytokine-induced TH1/TH2 differentiation (85). Therefore TAPP may potentially play a role in cytokine signaling in T lymphocytes by promoting membrane localization or activity of PTPL1. Although much is known about Bam32 and TAPP's function in B cells, it remains to determine whether there is a physiological function for the adapters proteins that involves $\mathrm{T}$ cell signaling.

\section{SHIP1 AND SOLUBLE INOSITOL PHOSPHATE IP 4}

In addition to hydrolysis of $\mathrm{PI}(3,4,5) \mathrm{P}_{3}$, SHIP1 can also dephosphorylate soluble inositol-1,3,4,5 tetrakisphosphate $\left(\mathrm{IP}_{4}\right)$ in vitro $(18,86) . \mathrm{IP}_{4}$ is generated by phosphorylation of $\operatorname{Ins}(1,4,5) \mathrm{P}_{3}\left(\mathrm{IP}_{3}\right)$ at its 3-position by $\mathrm{IP}_{3} 3$-Kinases $\left(\mathrm{IP}_{3} 3 \mathrm{~K}\right)$ (Figure 1). Mammals express four IP3Ks; ItpkA/B/C and IPMK (IP multikinase). Lymphocytes predominantly express two Iptks, IptkB, and Iptkc, while IptkC is expressed in many tissues, expression of IptkB is restricted to hematopoietic cells and brain $(2,87)$. IP4 is required for T cell development as $I t p k b^{-1-}$ mice, are severely immunocompromised and lack mature $\mathrm{T}$ cells because of a block at the $\mathrm{CD} 4^{+} \mathrm{CD} 8^{+}$ DP stage due to impaired positive selection in the thymus (88, 89). Interestingly, PLC $\gamma$ mediated DAG-induced ERK activation which is essential for positive selection is profoundly impaired in $I t p k b^{-1-}$ mice (90). $\mathrm{IP}_{4}$ strongly resembles the phosphate headgroup of $\mathrm{PI}(3,4,5) \mathrm{P}_{3}$ and therefore it can bind to $\mathrm{PH}$-domain containing proteins that also bind to $\mathrm{PI}(3,4,5) \mathrm{P}_{3}$ (e.g., ITK, AKT) and perhaps several others (2). In T cells IP4 functions as a second messenger and regulates Itk membrane recruitment and activation upon TCR stimulation and therefore it is essential for full activation of ITK and its effector PLC $\gamma$ (90). At physiological concentrations of IP4 in TCR stimulated T cells it promotes ITK binding to $\mathrm{PI}(3,4,5) \mathrm{P}_{3}$, whereas at high IP4 concentrations it competes with $\mathrm{PI}(3,4,5) \mathrm{P}_{3}$ for $\mathrm{PH}$-domain binding (2). Because of the essential role of IP4 in T cell development and function it would be intriguing to know whether IP4 turnover at in primary $\mathrm{T}$ cells is regulated by SHIP1 5' phosphatase activity. This might be investigated by determining the measuring IP4 levels in SHIP1-deficient $\mathrm{T}$ cells (vs. WT) to provide evidence of negative regulation of IP4 by SHIP1 in vivo. If this appears to be the case, then it would then be interesting to test whether the increased IP4 concentration in SHIP $1^{-1-} \mathrm{T}$ cells results in diminished $\mathrm{PI}(3,4,5) \mathrm{P}_{3}$ binding of $\mathrm{PH}$-domain signaling proteins recruited to $\mathrm{PI}(3,4,5) \mathrm{P}_{3}$ (e.g., ItK or AKT) to regulate $\mathrm{T}$ cell function.

\section{SHIP2}

A close homolog of SHIP1 is the ubiquitously expressed $150 \mathrm{kDa}$ protein SHIP2. Unlike SHIP1, whose expression is confined to hematolymphoid cells, osteoblasts (24), and mesenchymal stem cells (91). SHIP2 is expressed broadly in both hematopoietic and non-hematopoietic tissues such as brain, skeletal muscle, heart, liver, and kidney $(92,93)$. SHIP2 hydrolyzes the $5^{\prime}$ phosphate of $\mathrm{PI}(3,4,5) \mathrm{P}_{3}$ in vitro and in vivo and has also been shown to dephosphorylate $\mathrm{PI}(4,5) \mathrm{P}_{2}$ in vitro $(94,95)$. Thus, it may not be restricted to hydrolysis of the $5^{\prime} \mathrm{PO}_{4}$ groups on $3^{\prime} \mathrm{PO}_{4}$-containing polyphosphates, $\mathrm{PI}(3,4,5) \mathrm{P} 3$ and $\mathrm{I}(1,3,4,5) \mathrm{P} 4$, like its close homolog SHIP1. SHIP2 is tyrosine phosphorylated upon stimulation with stem cell factor (SCF), interleukin-3 (IL-3), and granulocytemacrophage colony-stimulating factor (GM-CSF), which results in its association with SHC (src homologous and collagen gene). Suggesting that SHIP2, similarly to SHIP1, is linked to downstream signaling events after activation of hematopoietic growth factor receptors. SHIP2 plays a major role in negatively regulating insulin signaling in non-immune cells (93). Bruyns et al. reported that both SHIP1 and SHIP2 are expressed in human T lymphocytes with only SHIP2 protein levels increased after long-term stimulation of the TCR (96). SHIP2 has also been shown to associate with the SH3 domain of Tec kinase and inhibit Tec-mediated TCR signaling (35). However, a physiological role for SHIP2 in T cell biology and function remains to be demonstrated and defined.

In addition to SHIP1 and SHIP2, eight other $5^{\prime}$ phosphatases have been reported; OCRL1 (oculocerebrorenal syndrome of Lowe), synaptojanin1, synaptojanin 2, proline rich inositol poly-phosphate 5-phosphatase (PIPP), 72-5ptase/Type IV/Inpp5e, SKIP, INPP5B, and 5-phosphatase1. With the exception of 5-phosphatase1 that hydrolyzes only the soluble inositol phosphates Ins $(1,4,5) \mathrm{P}_{3}$ and $\operatorname{Ins}(1,3,4,5) \mathrm{P}_{4}$, other phosphatases can dephosphorylate 5-phosphorylated phosphoinositides including PtdIns $(4,5) \mathrm{P}_{2}$, PtdIns $(3,4,5) \mathrm{P}_{3}$, PtdIns $(3,5) \mathrm{P}_{2}$, and soluble inositol phosphates although with variable efficiency (95). Some of these phosphatases are implicated in human diseases, for instance OCRL1 mutations are associated with Lowe's syndrome and Dent 2 disease $(95,97)$, SKIP and 72-5ptase/Type IV/Inpp5e are implicated in insulin signaling and glucose homeostasis while Synaptogenin 1 in mice is required for neuronal function. Overlapping functions for some of the 5'phosphatases have been reported for example OCRL1 ${ }^{-}{ }^{-}$mice do not develop Lowe's disease since loss of OCRL1 was compensated by a highly homologous protein Inpp5b (98). Thus far no immune phenotype has been reported in any mouse mutant of these other $5^{\prime}$ inositol phosphatases. However, further studies are merited to rigorously exclude a specific role in $\mathrm{T}$ cell signaling.

\section{PHOSPHATASE AND TENSIN HOMOLOG (PTEN)}

Phosphatase and tensin homolog deleted on chromosome 10 was originally identified as a tumor suppressor gene, which negatively regulates cell survival and proliferation and is mutated in several cancers $(99,100)$. PTEN germline mutations are associated with several hereditary disorders characterized by hamartomas and increased cancer risk such as Cowden syndrome, BannayanRiley-Ruvalcaba syndrome, Proteus syndrome, and Proteus-like syndrome, collectively classified as PTEN hamartoma tumor syndrome (PHTS) (101). PTEN predominantly acts as a $3^{\prime}$ lipid phosphatase to oppose PI3K signaling by dephosphorylating $\mathrm{PI}(3,4,5) \mathrm{P}_{3}$, a product of $\mathrm{PI} 3 \mathrm{~K}$, at its $3^{\prime}$ hydroxyl position to yield $\mathrm{PI}(4,5) \mathrm{P}_{2}$ (102). Other than its $3^{\prime}$ lipid phosphatase activity, PTEN also possess protein phosphatase activity and has been reported to dephosphorylate focal adhesion kinase (FAK) by direct binding (103). Homozygous PTEN $^{-1-}$ knockout mice die early during embryogenesis, precluding analysis of PTEN role in various adult tissues and organs in germline mutant mice. However a wide range 
of information has been collected from studies using mice heterozygous for PTEN or lacking PTEN in various tissues using Cre-loxP models (21). Table 1 summarizes the function PTEN in $\mathrm{T}$ cells in different genetic mouse models.

Phosphatase and tensin homolog heterozygous mice show high tumor incidence, impaired Fas mediated cell death, and develop autoimmune disorders. T cells from these mice show increased proliferation, reduced activation induced cell death suggesting an important role of PTEN in T cell survival and activation (51). Studies from mice lacking PTEN in T cells revealed an important role for PTEN in T cell development, function, and homeostasis (22). Mice lacking PTEN in T cells (LckCre-PTEN ${ }^{\text {flox/- }}$ ) die prematurely due to CD4 ${ }^{+} \mathrm{T}$ cell lymphomas and develop symptoms of autoimmunity like autoantibody production and hypergammaglobulinemia. These mice show defective lineage commitment, altered thymic selection, and impaired peripheral tolerance. T cells from these mice were hyper-proliferative, secreted increased levels of Th1/Th2 cytokines, and were autoreactive. Resistance to apoptosis, increased AKT and ERK phosphorylation, and increased $\mathrm{Bcl}-\mathrm{X}_{\mathrm{L}}$ expression were observed in these $\mathrm{T}$ cells suggesting a vital role PTEN in regulation of $\mathrm{T}$ cell survival and apoptosis signaling (22). Hagenbeek et al. further confirmed the role of PTEN in T cell survival and development by analyzing LckCre-PTEN ${ }^{\text {flox/flox }}$ mice. They showed that in the absence of PTEN there is a diminished requirement for both IL-7R and pre-TCR signaling in T cell development and proliferation (52). PTEN deficient CD4 ${ }^{+} \mathrm{T}$ cells show hyper-responsiveness to TCR stimulation without requirement for co-stimulation signals and are refractory to anergy induction. Moreover, PTEN ${ }^{-1-}$ T cells show increased AKT and GSK3 $\beta$ phosphorylation and enhanced IL-2 production upon TCR stimulation. This suggests that by negatively regulating TCR signaling, PTEN sets a threshold for $\mathrm{T}$ cell activation and imposes a requirement for co-stimulation and thus regulates T cell anergy (104). PTEN regulates the response of Tregs to IL-2 and plays a negative role in IL-2R signaling in Tregs, which normally do not expand in response to IL-2 alone. However, when Treg cells are deficient in PTEN they can proliferate upon IL-2 stimulation without the requirement for TCR stimulation (53). PTEN deficient CD4 T cells also produce more Th2 cytokines (IL-4, IL-10) in response to TCR stimulation alone or in combination with CD28 suggesting a role of PTEN in regulation Th2 cytokine production (105). Thus PTEN negatively regulates the TCR signaling and the induction of key cytokines. Thus, efficient and sustained TCR signaling and cytokine responses by $\mathrm{T}$ cells requires down-modulation of PTEN which occurs following TCR stimulation (106). Further Cbl-b has been shown to regulate down-modulation of PTEN in response to TCR/CD28 stimulation by inhibiting PTEN association with Nedd4, which targets PTEN K13 for K63-linked polyubiquitination suggesting that multiple pathways may regulate PTEN in the context to TCR/CD28 stimulation (107).

Studies from various knockout models showed clearly that PTEN plays an important role as a tumor and autoimmunity suppressor. However, the mechanistic insights into the relationship of these two functions of PTEN in T cells revealed that these two functions of PTEN are distinct, context dependent and are mediated in $\mathrm{T}$ cells at different developmental stages. By using mice with deletion of PTEN in T cells (CD4CrePten ${ }^{\mathrm{fl} / \mathrm{fl}}$ ), Liu et al. demonstrated that $\mathrm{T}$ cell lymphomas arise in the thymus whereas autoimmunity was mediated by mature peripheral $\mathrm{T}$ cells (108). Subsequently Soond et al. studied the role of PTEN in mature CD4 $\mathrm{T}_{\mathrm{H}}$ cells by using OX40CrePten ${ }^{\text {flox }}$ mice. Contrary to models of thymocyte-specific PTEN deletion OX40CrePten ${ }^{\text {flox }}$ mice did not develop lymphomas and autoimmunity even at an advanced age suggesting that PTEN does not act as a tumor suppressor or repressor of autoimmunity in mature $\mathrm{T}$ cells. In fact, PTEN deficient CD4 $\mathrm{T}_{\mathrm{H}}$ cells produced increased concentrations of cytokines and were hyper-proliferative. The authors postulated that enhanced cytokine production turned PTEN deficient $\mathrm{T}_{\mathrm{H}}$ cells into "super-helpers" as enhanced inflammatory, antibacterial, and anti-tumor responses were observed in OX40 ${ }^{\text {cre }}$ Pten $^{\text {flox }}$ mice (54). Thus contrary to the prevalent view PTEN does not essentially always function as a tumor suppressor or immune-suppressor and can also, like SHIP1, have varied functions depending on cell type, developmental stage of cell, and biological context. This was further confirmed by a recent study by Locke et al. by employing a model where PTEN is deleted in post-thymic $\mathrm{T}$ cells. They observed enhanced cytokine production, proliferation, and activation of post-thymic PTEN deleted T cells. As observed earlier, these effects were associated with increased AKT activity. However, CD28 independence and anergy resistance were not observed (109). Enhanced cytokine production, antibacterial, and anti-tumor responses of PTEN deficient $\mathrm{T}$ cells argue that therapeutic strategies targeting pharmacological inhibition of PTEN may prove attractive in immunotherapeutic strategies that require enhanced $\mathrm{T}$ effector function. Recently small molecule inhibitors of PTEN has been identified and used in vivo without causing prominent toxicity $(110,111)$. However, further studies are required to assess the role of these inhibitors on $\mathrm{T}$ cell effector and regulatory functions before considering their use in immunotherapeutic approaches.

\section{INOSITOL POLY-PHOSPHATE 4-PHOSPHATASE (INPP4)}

Inositol poly-phosphate 4-phosphatases are a class of enzymes that has two isoforms INPP4A and INPP4B, that selectively remove the phosphate group at position 4 on the inositol ring to convert $\mathrm{PI}(3,4) \mathrm{P}_{2}$ to $\mathrm{PI}(3) \mathrm{P}(112)$. In contrast to INPP4A, which is predominantly expressed in brain, INPP4B is highly expressed in skeletal muscle, heart, brain, and pancreas, epithelial cells of the breast, and prostate glands (113). INPP4A has been shown to regulate neuroexcitatory cell death whereas INPP4B has emerged as potent tumor suppressor in breast cancer $(114,115)$. The function of the INPP4A and INPP4B phosphatases in immune cells has not been investigated, although a prominent role for INPP4B in myeloid-derived osteoclast function and bone remodeling has been shown (116). Thus, further investigation of these $4^{\prime}$-phosphatases appears merited and particularly in cell types and immune contexts where SHIP1 has a positive signaling role (e.g., T cell survival the gut). Function of inositol phosphatases in T cells is summarized is Figure 2.

\section{CONCLUDING REMARKS}

Consistent with studies implicating class I PI3K in T cell biology, the inositol phosphatases, SHIP1 and PTEN, have been documented to be important regulators of PI3K signaling pathway in T cells. Although SHIP1 and PTEN by dephosphorylating the $\mathrm{PI}(3,4,5) \mathrm{P}_{3}$ negatively regulate $\mathrm{PI} 3 \mathrm{~K}$ signaling, their in vivo 


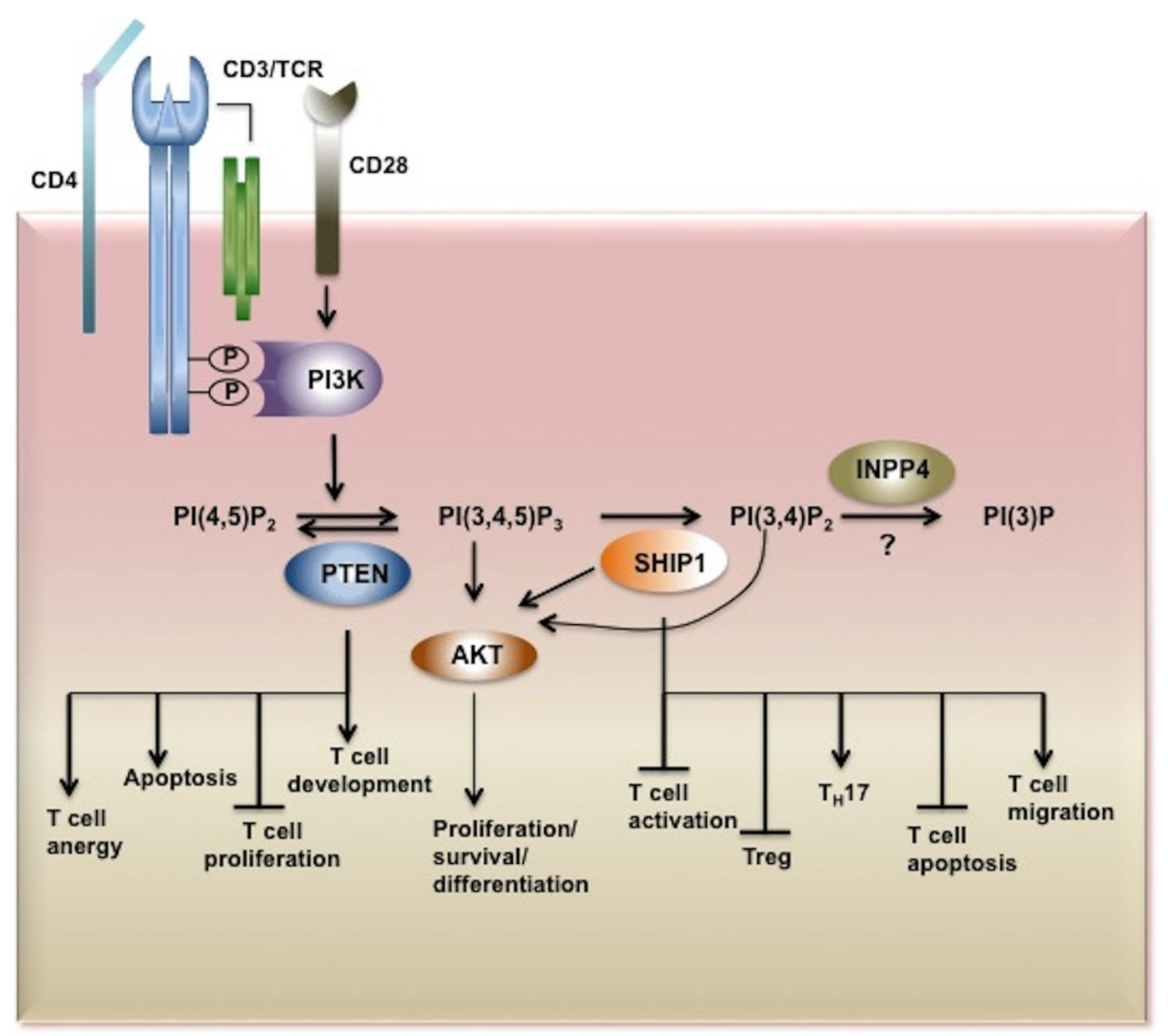

FIGURE 2 | Inositol phosphatases in T cell biology. Upon TCR stimulation $\mathrm{PI} 3 \mathrm{~K}$ is activated and recruited to the membrane through its $\mathrm{SH} 2$ domain where it phosphorylates its substrate $\mathrm{PI}(4,5) \mathrm{P}_{2}$ converting it to $\mathrm{PI}(3,4,5) \mathrm{P}_{3}$. $\mathrm{PI}(3,4,5) \mathrm{P}_{3}$ is bound by $\mathrm{PH}$-domain containing proteins such as AKT, PDK1, BTK, ITK, Vav, and PLC $\gamma$ triggering secondary signaling cascades and thus $T$ cell activation, proliferation, survival, and cytokine production. PI3K signaling is tightly regulated by inositol phosphatases. $\mathrm{PI}(3,4,5) \mathrm{P}_{3}$ is a substrate for three inositol phosphatases, SHIP1/2 and PTEN which hydrolyze PI $(3,4,5) \mathrm{P}_{3}$ to
$\mathrm{PI}(3,4,) \mathrm{P}_{2}$ and $\mathrm{PI}(4,5) \mathrm{P}_{2}$, respectively. By limiting the cellular pool of the second messenger $\mathrm{PI}(3,4,5) \mathrm{P}_{3}$, PTEN and SHIP play important functions in T cell development, proliferation, and activation. The SHIP1 product PI $(3,4) \mathrm{P}_{2}$ which can also recruit and activate AKT is dephosphorylated by INPP4. However the role of these 4-phosphatases in T cell biology has yet to be determined. AKT, Protein Kinase B; PDK1, phosphoinositide-dependent kinase-1, PLC $\gamma$ phospholipase $\mathrm{C}_{\gamma}$; ITK, IL-2-inducible T cell kinase) and BTK, Bruton agammaglobulinemia tyrosine kinase. functions in this signaling pathway, as reveled by genetic analysis, diverge significantly. SHIP1 appears to be required for the survival of $\mathrm{T}$ cells in vivo, and particularly in the lamina propria, while PTEN inhibits $\mathrm{T}$ cell proliferation and prevents from lymphoproliferative syndromes. Therefore these phosphatases at the cellular level provide a fine balance of PI3K signaling necessary for the proper activation and development of $\mathrm{T}$ cells in order to avoid immunopathology. As SHIP1 deficiency has been shown to promote $\mathrm{T}$ cell apoptosis there is a significant potential for SHIP1 inhibitors, which have already shown promising results in cancer $(43,73)$, to be used to target autoreactive T cells in IBD conditions. Although PTEN has been shown to regulate CD4 T cell function and tolerance little is known about its role in other T cell subtypes. Further studies are therefore required to dissect PTEN signaling in T cells before therapeutic application of
PTEN inhibitors in immunotherapy for cancer could be considered. In addition, the role of other lipid phosphatases SHIP2 and INNP4, which regulate the cellular pools of PtdIns $(3,4,5) \mathrm{P}_{3}$ and $\mathrm{PI}(3,4) \mathrm{P}_{2}$, respectively, merit examination in vivo in the coming years using sophisticated genetic models that enable conditional and/or inducible ablation of their expression in specific $\mathrm{T}$ cell populations.

\section{ACKNOWLEDGMENTS}

This work was supported in part by grants from the NIH (RO1 HL72523, R01 HL085580, R01 HL107127) and the Paige Arnold Butterfly Run. William Garrow Kerr is the Murphy Family Professor of Children's Oncology Research, an Empire Scholar of the State University of NY and a Senior Scholar of the Crohn's and Colitis Foundation. 


\section{REFERENCES}

1. Fayard E, Moncayo G, Hemmings BA, Hollander GA. Phosphatidylinositol 3-kinase signaling in thymocytes: the need for stringent control. Sci Signal (2010) 3:re5. doi:10.1126/scisignal.3135re5

2. Huang YH, Sauer K. Lipid signaling in T-cell development and function. Cold Spring Harb Perspect Biol (2010) 2:a002428. doi:10. 1101/cshperspect.a002428

3. Okkenhaug K, Vanhaesebroeck B. PI3K in lymphocyte development, differentiation and activation. Nat Rev Immunol (2003) 3:317-30. doi:10.1038/nri1056

4. So L, Fruman DA. PI3K signalling in B- and Tlymphocytes: new developments and therapeutic advances. Biochem J (2012) 442:465-81. doi:10.1042/BJ20112092

5. Lemmon MA. Membrane recognition by phospholipid-binding domains. Nat Rev Mol Cell Biol (2008) 9:99-111. doi:10.1038/ nrm2328

6. Fayard E, Xue G, Parcellier A, Bozulic L, Hemmings BA. Protein kinase $\mathrm{B}$ (PKB/Akt), a key mediator of the PI3K signaling pathway. Curr Top Microbiol Immunol (2010) 346:31-56. doi: 10.1007/82_2010_58

7. Fruman DA. Phosphoinositide 3kinase and its targets in B-cell and T-cell signaling. Curr Opin Immunol (2004) 16:314-20. doi: 10.1016/j.coi.2004.03.014

8. Janas ML, Varano G, Gudmundsson $\mathrm{K}$, Noda M, Nagasawa T, Turner M. Thymic development beyond beta-selection requires phosphatidylinositol 3-kinase activation by CXCR4. J Exp Med (2010) 207:247-61. doi:10.1084/ jem. 20091430

9. Ji H, Rintelen F, Waltzinger C, Bertschy Meier D, Bilancio A, Pearce $\mathrm{W}$, et al. Inactivation of PI3Kgamma and PI3Kdelta distorts T-cell development and causes multiple organ inflammation. Blood (2007) 110:2940-7. doi:10.1182/blood-2007-04086751

10. Shiroki F, Matsuda S, Doi T, Fujiwara M, Mochizuki Y, Kadowaki $\mathrm{T}$, et al. The p85alpha regulatory subunit of class IA phosphoinositide 3-kinase regulates beta-selection in thymocyte development. J Immunol (2007) 178:1349-56.

11. Swat W, Montgrain V, Doggett TA, Douangpanya J, Puri K, Vermi W, et al. Essential role of PI3Kdelta and PI3Kgamma in thymocyte survival. Blood (2006) 107:2415-22. doi:10.1182/blood-2005-08-3300

12. Webb LM, Vigorito E, Wymann MP, Hirsch E, Turner M. Cutting edge: $\mathrm{T}$ cell development requires the combined activities of the p110gamma and p110delta catalytic isoforms of phosphatidylinositol 3-kinase. J Immunol (2005) 175:2783-7.

13. Okkenhaug K, Patton DT, Bilancio A, Garcon F, Rowan WC, Vanhaesebroeck B. The p110delta isoform of phosphoinositide 3-kinase controls clonal expansion and differentiation of Th cells. J Immunol (2006) 177:5122-8.

14. Patton DT, Garden OA, Pearce WP, Clough LE, Monk CR, Leung $\mathrm{E}$, et al. Cutting edge: the phosphoinositide 3-kinase p110 delta is critical for the function of CD4+CD25+Foxp3+ regulatory T cells. J Immunol (2006) 177:6598-602.

15. Patton DT, Wilson MD, Rowan WC, Soond DR, Okkenhaug K. The PI3K p110delta regulates expression of $\mathrm{CD} 38$ on regulatory $\mathrm{T}$ cells. PLoS One (2011) 6:e17359. doi:10. 1371/journal.pone.0017359

16. Deane JA, Kharas MG, Oak JS, Stiles LN, Luo J, Moore TI, et al. T-cell function is partially maintained in the absence of class IA phosphoinositide 3kinase signaling. Blood (2007) 109:2894-902.

17. Oak JS, Deane JA, Kharas MG, Luo J, Lane TE, Cantley LC, et al. Sjogren's syndrome-like disease in mice with $\mathrm{T}$ cells lacking class $1 \mathrm{~A}$ phosphoinositide-3kinase. Proc Natl Acad Sci U S A (2006) 103:16882-7. doi:10.1073/ pnas.0607984103

18. Damen JE, Liu L, Rosten P, Humphries RK, Jefferson $\mathrm{AB}$, Majerus $\mathrm{PW}$, et al. The $145-\mathrm{kDa}$ protein induced to associate with She by multiple cytokines is an inositol tetraphosphate and phosphatidylinositol 3,4,5-triphosphate 5phosphatase. Proc Natl Acad Sci U S A (1996) 93:1689-93. doi:10.1073/pnas.93.4.1689

19. Di Cristofano A, Pesce B, CordonCardo C, Pandolfi PP. Pten is essential for embryonic development and tumour suppression. Nat Genet (1998) 19:348-55. doi: $10.1038 / 1235$

20. Helgason CD, Damen JE, Rosten P, Grewal R, Sorensen P, Chappel SM, et al. Targeted disruption of SHIP leads to hemopoietic perturbations, lung pathology, and a shortened life span. Genes Dev (1998) 12:1610-20.

21. Suzuki A, Nakano T, Mak TW Sasaki T. Portrait of PTEN: messages from mutant mice. Cancer Sci (2008) 99:209-13. doi:10.1111/ j.1349-7006.2007.00670.x

22. Suzuki A, Yamaguchi MT, Ohteki T, Sasaki T, Kaisho T, Kimura $\mathrm{Y}$, et al. $\mathrm{T}$ cell-specific loss of Pten leads to defects in central and peripheral tolerance. Immunity (2001) 14:523-34. doi:10. 1016/S1074-7613(01)00134-0

23. Kerr WG. Inhibitor and activator: dual functions for SHIP in immunity and cancer. Ann N Y Acad Sci (2011) 1217:1-17. doi:10.1111/ j.1749-6632.2010.05869.x

24. Hazen AL, Smith MJ, Desponts C, Winter O, Moser K, Kerr WG. SHIP is required for a functional hematopoietic stem cell niche. Blood (2009) 113:2924-33. doi:10. 1182/blood-2008-02-138008

25. Osborne MA, Zenner G, Lubinus $M$, Zhang $X$, Songyang $Z$ Cantley LC, et al. The inositol 5'-phosphatase SHIP binds to immunoreceptor signaling motifs and responds to high affinity IgE receptor aggregation. J Biol Chem (1996) 271:29271-8. doi:10.1074/ jbc.271.46.29271

26. Pesesse X, Backers K, Moreau C, Zhang J, Blero D, Paternotte N, et al. SHIP1/2 interaction with tyrosine phosphorylated peptides mimicking an immunoreceptor signalling motif. Adv Enzyme Regul (2006) 46:142-53. doi:10.1016/j. advenzreg.2006.01.013

27. Dowler S, Currie RA, Campbell DG, Deak M, Kular G, Downes $\mathrm{CP}$, et al. Identification of pleckstrin-homologydomain-containing proteins with novel phosphoinositidebinding specificities. Biochem J (2000) 351:19-31. doi:10.1042/0264-6021:3510019

28. Lemmon MA, Ferguson KM. Signal-dependent membrane targeting by pleckstrin homology (PH) domains. Biochem J (2000) 350(Pt 1):1-18. doi:10.1042/02646021:3500001

29. Kerr WG, Park MY, Maubert M, Engelman RW. SHIP deficiency causes Crohn's disease-like ileitis. Gut (2011) 60:177-88. doi:10. 1136/gut.2009.202283

30. Ghansah T, Paraiso KH, Highfill S, Desponts C, May S, McIntosh $\mathrm{JK}$, et al. Expansion of myeloid suppressor cells in SHIPdeficient mice represses allogeneic
T cell responses. J Immunol (2004) 173:7324-30

31. Edmunds C, Parry RV, Burgess SJ, Reaves B, Ward SG. CD28 stimulates tyrosine phosphorylation, cellular redistribution and catalytic activity of the inositol lipid 5-phosphatase SHIP. Eur J Immunol (1999) 29:3507-15. doi:10.1002/(SICI) 1521-4141(199911)29:11<3507: :AID-IMMU3507>3.0.CO;2-9

32. Dong S, Corre B, Foulon E, Dufour E, Veillette A, Acuto O, et al. T cell receptor for antigen induces linker for activation of $\mathrm{T}$ celldependent activation of a negative signaling complex involving Dok2, SHIP-1, and Grb-2. J Exp Med (2006) 203:2509-18. doi:10.1084/ jem.20060650

33. Waterman PM, Marschner S, Brandl E, Cambier JC. The inositol 5-phosphatase SHIP-1 and adaptors Dok-1 and 2 play central roles in CD4-mediated inhibitory signaling. Immunol Lett (2012) 143:122-30. doi:10.1016/j. imlet.2012.02.009

34. Scharenberg AM, El-Hillal O, Fruman DA, Beitz LO, Li Z, Lin $\mathrm{S}$, et al. Phosphatidylinositol3,4,5-trisphosphate (PtdIns-3,4,5P3)/Tec kinase-dependent calcium signaling pathway: a target for SHIP-mediated inhibitory signals. EMBO J (1998) 17:1961-72. doi: 10.1093/emboj/17.7.1961

35. Tomlinson MG, Heath VL, Turck CW, Watson SP, Weiss A. SHIP family inositol phosphatases interact with and negatively regulate the Tec tyrosine kinase. J Biol Chem (2004) 279:55089-96. doi: 10.1074/jbc.M408141200

36. Kashiwada M, Cattoretti G, McKeag L, Rouse T, Showalter BM, Al-Alem U, et al. Downstream of tyrosine kinases-1 and Src homology 2-containing inositol 5 '-phosphatase are required for regulation of $\mathrm{CD} 4+\mathrm{CD} 25+\mathrm{T}$ cell development. J Immunol (2006) 176:3958-65.

37. Tarasenko T, Kole HK, Chi AW, Mentink-Kane MM, Wynn TA Bolland S. T cell-specific deletion of the inositol phosphatase SHIP reveals its role in regulating Th1/Th2 and cytotoxic responses. Proc Natl Acad Sci US A (2007) 104:11382-7. doi:10.1073/ pnas.0704853104

38. Leung WH, Tarasenko T, Bolland S. Differential roles for the inositol phosphatase SHIP in the regulation of macrophages and lymphocytes. Immunol Res 
(2009) 43:243-51. doi:10.1007/ s12026-008-8078-1

39. Maxwell MJ, Duan M, Armes JE, Anderson GP, Tarlinton DM, Hibbs ML. Genetic segregation of inflammatory lung disease and autoimmune disease severity in SHIP-1-/- mice. J Immunol (2011) 186:7164-75. doi:10.4049/ jimmunol.1004185

40. Peng Q, Malhotra S, Torchia JA, Kerr WG, Coggeshall KM, Humphrey MB. TREM2- and DAP12-dependent activation of $\mathrm{PI} 3 \mathrm{~K}$ requires DAP10 and is inhibited by SHIP1. Sci Signal (2010) 3:ra38. doi:10.1126/ scisignal.2000500

41. Wahle JA, Paraiso KH, Kendig RD, Lawrence HR, Chen L, Wu $\mathrm{J}$, et al. Inappropriate recruitment and activity by the Src homology region 2 domain-containing phosphatase 1 (SHP1) is responsible for receptor dominance in the SHIP-deficient NK cell. J Immunol (2007) 179:8009-15.

42. Fernandes S, Iyer S, Kerr WG. Role of SHIP1 in cancer and mucosal inflammation. Ann NY Acad Sci (2013) 1280:6-10. doi:10. 1111/nyas. 12038

43. Brooks R, Fuhler GM, Iyer S, Smith MJ, Park MY, Paraiso KH, et al. SHIP1 inhibition increases immunoregulatory capacity and triggers apoptosis of hematopoietic cancer cells. J Immunol (2010) 184:3582-9. doi:10.4049/ jimmunol.0902844

44. Collazo MM, Paraiso KH, Park MY, Hazen AL, Kerr WG. Lineage extrinsic and intrinsic control of immunoregulatory cell numbers by SHIP. Eur J Immunol (2012) 42:1785-95. doi:10.1002/ eji.201142092

45. Collazo MM, Wood D, Paraiso KH, Lund E, Engelman RW, Le CT, et al. SHIP limits immunoregulatory capacity in the T-cell compartment. Blood (2009) 113:2934-44. doi:10.1182/blood-2008-09181164

46. Paraiso KH, Ghansah T, Costello A, Engelman RW, Kerr WG. Induced SHIP deficiency expands myeloid regulatory cells and abrogates graft-versus-host disease. J Immunol (2007) 178:2893-900.

47. Locke NR, Patterson SJ, Hamilton MJ, Sly LM, Krystal G, Levings MK. SHIP regulates the reciprocal development of $\mathrm{T}$ regulatory and Th17 cells. J Immunol (2009) 183:975-83. doi:10.4049/ jimmunol.0803749
48. O'Connell RM, Chaudhuri AA, Rao DS, Baltimore D. Inositol phosphatase SHIP1 is a primary target of miR-155. Proc Natl Acad Sci U S A (2009) 106:7113-8. doi: 10.1073/pnas.0902636106

49. Marson A, Kretschmer K, Frampton GM, Jacobsen ES, Polansky JK, MacIsaac KD, et al. Foxp3 occupancy and regulation of key target genes during T-cell stimulation. Nature (2007) 445:931-5. doi:10. 1038/nature05478

50. Zheng Y, Josefowicz SZ, Kas A, Chu TT, Gavin MA, Rudensky AY. Genome-wide analysis of Foxp3 target genes in developing and mature regulatory T cells. Nature (2007) 445:936-40. doi:10.1038/ nature 05563

51. Di Cristofano A, Kotsi P, Peng YF, Cordon-Cardo C, Elkon KB, Pandolfi PP. Impaired Fas response and autoimmunity in Pten \pm mice. Science (1999) 285:2122-5. doi:10. 1126/science.285.5436.2122

52. Hagenbeek TJ, Naspetti M, Malergue F, Garcon F, Nunes JA, Cleutjens $\mathrm{KB}$, et al. The loss of PTEN allows TCR alphabeta lineage thymocytes to bypass IL-7 and PreTCR-mediated signaling. $J$ Exp Med (2004) 200:883-94. doi:10. 1084/jem.20040495

53. Walsh PT, Buckler JL, Zhang J, Gelman AE, Dalton NM, Taylor DK, et al. PTEN inhibits IL2 receptor-mediated expansion of CD4+ CD25+ Tregs. J Clin Invest (2006) 116:2521-31.

54. Soond DR, Garcon F, Patton DT, Rolf J, Turner M, Scudamore C, et al. Pten loss in CD4 $\mathrm{T}$ cells enhances their helper function but does not lead to autoimmunity or lymphoma. J Immunol (2012) 188:5935-43. doi:10.4049/ jimmunol.1102116

55. Afonso PV, Parent CA. PI 3 K and chemotaxis: a priming issue? $\mathrm{Sci}$ Signal (2011) 4:e22. doi:10.1126/ scisignal.2002019

56. Ward SG. Do phosphoinositide 3-kinases direct lymphocyte navigation? Trends Immunol (2004) 25:67-74. doi:10.1016/j.it.2003.12. 003

57. Nishio M, Watanabe K, Sasaki J, Taya C, Takasuga S, Iizuka $\mathrm{R}$, et al. Control of cell polarity and motility by the $\operatorname{PtdIns}(3,4,5) \mathrm{P} 3$ phosphatase SHIP1. Nat Cell Biol (2007) 9:36-44. doi:10.1038/ ncb1515

58. Kim CH, Hangoc G, Cooper S, Helgason CD, Yew S, Humphries $\mathrm{RK}$, et al. Altered responsiveness to chemokines due to targeted disruption of SHIP. J Clin Invest (1999) 104:1751-9. doi:10.1172/ JCI7310

59. Wain CM, Westwick J, Ward SG. Heterologous regulation of chemokine receptor signaling by the lipid phosphatase SHIP in lymphocytes. Cell Signal (2005) 17:1194-202. doi:10.1016/j.cellsig. 2004.12.009

60. Harris SJ, Parry RV, Foster JG, Blunt MD, Wang A, Marelli-Berg F, et al. Evidence that the lipid phosphatase SHIP-1 regulates T lymphocyte morphology and motility. J Immunol (2011) 186:4936-45. doi:10.4049/jimmunol.1002350

61. Nijhara R, van Hennik PB, Gignac ML, Kruhlak MJ, Hordijk PL, Delon J, et al. Racl mediates collapse of microvilli on chemokine-activated $\mathrm{T}$ lymphocytes. J Immunol (2004) 173:4985-93.

62. Al-Alwan M, Hou S, Zhang TT, Makondo K, Marshall AJ. Bam32/DAPP1 promotes B cell adhesion and formation of polarized conjugates with $\mathrm{T}$ cells. $J$ Immunol (2010) 184:6961-9. doi: 10.4049/jimmunol.0904176

63. Boer AK, Drayer AL, Vellenga E. Effects of overexpression of the SH2-containing inositol phosphatase SHIP on proliferation and apoptosis of erythroid AS-E2 cells. Leukemia (2001) 15:1750-7. doi: 10.1038/sj.leu.2402261

64. Brauweiler A, Tamir I, Dal Porto J, Benschop RJ, Helgason CD, Humphries RK, et al. Differential regulation of B cell development, activation, and death by the src homology 2 domain-containing 5' inositol phosphatase (SHIP). J Exp Med (2000) 191:1545-54. doi:10. 1084/jem.191.9.1545

65. Gardai S, Whitlock BB, Helgason C, Ambruso D, Fadok V, Bratton D, et al. Activation of SHIP by NADPH oxidase-stimulated Lyn leads to enhanced apoptosis in neutrophils. J Biol Chem (2002) 277:5236-46. doi:10.1074/ jbc.M110005200

66. Valderrama-Carvajal $\mathrm{H}$, Cocolakis E, Lacerte A, Lee EH, Krystal G, Ali S, et al. Activin/TGFbeta induce apoptosis through Smad-dependent expression of the lipid phosphatase SHIP. Nat Cell Biol (2002) 4:963-9. doi:10.1038/ ncb885

67. Charlier E, Conde C, Zhang J, Deneubourg L, Di Valentin E, Rahmouni S, et al. SHIP-1 inhibits CD95/APO-1/Fas-induced apoptosis in primary $\mathrm{T}$ lymphocytes and $\mathrm{T}$ leukemic cells by promoting CD95 glycosylation independently of its phosphatase activity. Leukemia (2010) 24:821-32. doi: 10.1038/leu.2010.9

68. Gloire G, Charlier E, Rahmouni S, Volanti C, Chariot A, Erneux $\mathrm{C}$, et al. Restoration of SHIP1 activity in human leukemic cells modifies NF-kappaB activation pathway and cellular survival upon oxidative stress. Oncogene (2006) 25:5485-94. doi:10.1038/sj. onc. 1209542

69. Ono M, Okada H, Bolland S, Yanagi S, Kurosaki T, Ravetch JV. Deletion of SHIP or SHP1 reveals two distinct pathways for inhibitory signaling. Cell (1997) 90:293-301. doi:10.1016/ S0092-8674(00)80337-2

70. Pearse RN, Kawabe T, Bolland S, Guinamard R, Kurosaki T, Ravetch JV. SHIP recruitment attenuates Fc gamma RIIB-induced B cell apoptosis. Immunity (1999) 10:753-60. doi:10.1016/S10747613(00)80074-6

71. Franke TF, Kaplan DR, Cantley LC, Toker A. Direct regulation of the Akt proto-oncogene product by phosphatidylinositol3,4-bisphosphate [see comments]. Science (1997) 275:665-8. doi:10.1126/science. 275.5300.665

72. Ma K, Cheung SM, Marshall AJ, Duronio V. PI $(3,4,5) \mathrm{P} 3$ and $\mathrm{PI}(3,4) \mathrm{P} 2$ levels correlate with $\mathrm{PKB} / \mathrm{akt}$ phosphorylation at Thr308 and Ser473, respectively; $\mathrm{PI}(3,4) \mathrm{P} 2 \quad$ levels determine PKB activity. Cell Signal (2008) 20:684-94. doi:10.1016/j.cellsig.2007.12.004

73. Fuhler GM, Brooks R, Toms B, Iyer S, Gengo EA, Park MY, et al. Therapeutic potential of $\mathrm{SH} 2$ domain-containing inositol5'-phosphatase 1 (SHIP1) and SHIP2 inhibition in cancer. $\mathrm{Mol}$ Med (2012) 18:65-75. doi:10. 2119/molmed.2011.00178

74. Gewinner C, Wang ZC, Richardson A, Teruya-Feldstein J, Etemadmoghadam D, Bowtell D, et al. Evidence that inositol polyphosphate 4-phosphatase type II is a tumor suppressor that inhibits PI3K signaling. Cancer Cell (2009) 16:115-25. doi:10.1016/j.ccr.2009. 06.006

75. Ivetac I, Gurung R, Hakim S, Horan KA, Sheffield DA, Binge LC, et al. Regulation of PI(3)K/Akt signalling and cellular transformation by inositol polyphosphate 4-phosphatase-1. EMBO Rep 
(2009) 10:487-93. doi:10.1038/ embor.2009.28

76. Zhang TT, Li H, Cheung SM, Costantini JL, Hou S, Al-Alwan $\mathrm{M}$, et al. Phosphoinositide 3kinase-regulated adapters in lymphocyte activation. Immunol Rev (2009) 232:255-72. doi:10.1111/j. 1600-065X.2009.00838.x

77. Marshall AJ, Krahn AK, Ma K, Duronio V, Hou S. TAPP1 and TAPP2 are targets of phosphatidylinositol 3-kinase signaling in B cells: sustained plasma membrane recruitment triggered by the B-cell antigen receptor. Mol Cell Biol (2002) 22:5479-91. doi:10. 1128/MCB.22.15.5479-5491.2002

78. Kliche S, Breitling D, Togni M, Pusch R, Heuer K, Wang X, et al. The ADAP/SKAP55 signaling module regulates $\mathrm{T}$-cell receptor-mediated integrin activation through plasma membrane targeting of Rap1. Mol Cell Biol (2006) 26:7130-44. doi:10.1128/ MCB.00331-06

79. Zhang TT, Al-Alwan M, Marshall AJ. The pleckstrin homology domain adaptor protein Bam32/DAPP1 is required for germinal center progression. J Immunol (2010) 184:164-72. doi:10.4049/jimmunol.0902505

80. Rouquette-Jazdanian AK, Sommers CL, Kortum RL, Morrison DK, Samelson LE. LATindependent Erk activation via Bam32-PLC-gamma1Pak1 complexes: GTPaseindependent Pak1 activation. Mol Cell (2012) 48:298-312. doi:10.1016/j.molcel.2012.08.011

81. Sommers CL, Gurson JM, Surana R, Barda-Saad M, Lee J, Kishor A, et al. Bam32: a novel mediator of Erk activation in T cells. Int Immunol (2008) 20:811-8. doi:10. 1093/intimm/dxn039

82. Krahn AK, Ma K, Hou S, Duronio V, Marshall AJ. Two distinct waves of membrane-proximal B cell antigen receptor signaling differentially regulated by Src homology 2containing inositol polyphosphate 5-phosphatase. J Immunol (2004) 172:331-9.

83. Wullschleger S, Wasserman DH, Gray A, Sakamoto K, Alessi DR. Role of TAPP1 and TAPP2 adaptor binding to PtdIns $(3,4) \mathrm{P} 2$ in regulating insulin sensitivity defined by knock-in analysis. Biochem $J$ (2011) 434:265-74. doi:10.1042/ BJ20102012

84. Landego I, Jayachandran N, Wullschleger S, Zhang TT, Gibson IW, Miller A, et al.
Interaction of TAPP adapter proteins with phosphatidylinositol (3,4)-bisphosphate regulates $B$-cell activation and autoantibody production. Eur J Immunol (2012) 42:2760-70. doi:10.1002/eji.201242371

85. Kimber WA, Deak M, Prescott AR, Alessi DR. Interaction of the protein tyrosine phosphatase PTPL1 with the PtdIns(3,4)P2-binding adaptor protein TAPP1. Biochem $J$ (2003) 376:525-35. doi:10.1042/ BJ20031154

86. Lioubin MN, Algate PA, Tsai S, Carlberg K, Aebersold A, Rohrschneider LR. p150Ship, a signal transduction molecule with inositol polyphosphate5-phosphatase activity. Genes Dev (1996) 10:1084-95. doi:10.1101/gad.10.9.1084

87. Sauer K, Cooke MP. Regulation of immune cell development through soluble inositol1,3,4,5-tetrakisphosphate. Nat Rev Immunol (2010) 10:257-71. doi: $10.1038 /$ nri2745

88. Pouillon V, Hascakova-Bartova R, Pajak B, Adam E, Bex F, Dewaste V, et al. Inositol 1,3,4,5tetrakisphosphate is essential for T lymphocyte development. Nat Immunol (2003) 4:1136-43. doi: 10.1038/ni980

89. Wen BG, Pletcher MT, Warashina M, Choe SH, Ziaee N, Wiltshire $\mathrm{T}$, et al. Inositol $(1,4,5)$ trisphosphate 3 kinase $B$ controls positive selection of T cells and modulates Erk activity. Proc Natl Acad Sci U S A (2004) 101:5604-9. doi:10.1073/ pnas.0306907101

90. Huang YH, Grasis JA, Miller AT, Xu $\mathrm{R}$, Soonthornvacharin S, Andreotti $\mathrm{AH}$, et al. Positive regulation of Itk $\mathrm{PH}$ domain function by soluble IP4. Science (2007) 316:886-9. doi:10.1126/science. 1138684

91. Iyer S, Margulies BS, Kerr WG. Role of SHIP1 in bone biology. Ann N Y Acad Sci (2013) 1280:11-4. doi:10.1111/nyas.12091

92. Muraille E, Pesesse X, Kuntz C, Erneux C. Distribution of the srchomology-2-domain-containing inositol 5-phosphatase SHIP-2 in both non-haemopoietic and haemopoietic cells and possible involvement of SHIP-2 in negative signalling of B-cells. Biochem J (1999) 342(Pt 3):697-705. doi:10.1042/0264-6021:3420697

93. Wisniewski D, Strife A, Swendeman S, Erdjument-Bromage $\mathrm{H}$, Geromanos S, Kavanaugh $\mathrm{WM}$, et al. A novel SH2containing phosphatidylinositol 3,4,5-trisphosphate 5-phosphatase (SHIP2) is constitutively tyrosine phosphorylated and associated with src homologous and collagen gene (SHC) in chronic myelogenous leukemia progenitor cells. Blood (1999) 93:2707-20.

94. Nakatsu F, Perera RM, Lucast L, Zoncu R, Domin J, Gertler FB, et al. The inositol 5-phosphatase SHIP2 regulates endocytic clathrin-coated pit dynamics. J Cell Biol (2010) 190:307-15. doi:10.1083/jcb.201005018

95. Ooms LM, Horan KA, Rahman P, Seaton G, Gurung R, Kethesparan DS, et al. The role of the inositol polyphosphate 5-phosphatases in cellular function and human disease. Biochem J (2009) 419:29-49. doi:10.1042/BJ20081673

96. Bruyns C, Pesesse X, Moreau C, Blero D, Erneux C. The two SH2-domain-containing inositol 5-phosphatases SHIP1 and SHIP2 are coexpressed in human T lymphocytes. Biol Chem (1999) 380:969-74. doi:10.1515/BC.1999. 120

97. Attree O, Olivos IM, Okabe I, Bailey LC, Nelson DL, Lewis RA, et al. The Lowe's oculocerebrorenal syndrome gene encodes a protein highly homologous to inositol polyphosphate-5-phosphatase. Nature (1992) 358:239-42. doi:10. 1038/358239a0

98. Janne PA, Suchy SF, Bernard D, MacDonald M, Crawley J, Grinberg A, et al. Functional overlap between murine Inpp5b and Ocrl1 may explain why deficiency of the murine ortholog for OCRL1 does not cause Lowe syndrome in mice. J Clin Invest (1998) 101:2042-53. doi:10.1172/JCI2414

99. Li J, Yen C, Liaw D, Podsypanina K, Bose S, Wang SI, et al. PTEN, a putative protein tyrosine phosphatase gene mutated in human brain, breast, and prostate cancer. Science (1997) 275:1943-7. doi:10. 1126/science.275.5308.1943

100. Steck PA, Pershouse MA, Jasser SA, Yung WK, Lin $\mathrm{H}$, Ligon $\mathrm{AH}$, et al. Identification of a candidate tumour suppressor gene, MMAC1, at chromosome $10 \mathrm{q} 23.3$ that is mutated in multiple advanced cancers. Nat Genet (1997) 15:356-62. doi:10.1038/ng0497-356

101. Hobert JA, Eng C. PTEN hamartoma tumor syndrome: an overview. Genet Med (2009) 11:687-94. doi:10.1097/GIM. 0b013e3181ac9aea

102. Maehama T, Dixon JE. The tumor suppressor, PTEN/MMAC1, dephosphorylates the lipid second messenger, phosphatidylinositol 3,4,5-trisphosphate. J Biol Chem (1998) 273:13375-8. doi:10.1074/jbc.273.22.13375

103. Tamura M, Gu J, Danen EH, Takino T, Miyamoto S, Yamada KM. PTEN interactions with focal adhesion kinase and suppression of the extracellular matrixdependent phosphatidylinositol 3kinase/Akt cell survival pathway. $J$ Biol Chem (1999) 274:20693-703. doi:10.1074/jbc.274.29.20693

104. Buckler JL, Walsh PT, Porrett PM, Choi Y, Turka LA. Cutting edge: $\mathrm{T}$ cell requirement for CD28 costimulation is due to negative regulation of TCR signals by PTEN. $J$ Immunol (2006) 177:4262-6.

105. Buckler JL, Liu X, Turka LA. Regulation of $\mathrm{T}$-cell responses by PTEN. Immunol Rev (2008) 224:239-48. doi:10.1111/j.1600065X.2008.00650.x

106. Bensinger SJ, Walsh PT, Zhang J, Carroll M, Parsons R, Rathmell JC, et al. Distinct IL-2 receptor signaling pattern in $\mathrm{CD} 4+\mathrm{CD} 25+$ regulatory T cells. J Immunol (2004) 172:5287-96.

107. Guo H, Qiao G, Ying H, Li Z, Zhao Y, Liang Y, et al. E3 ubiquitin ligase $\mathrm{Cbl}-\mathrm{b}$ regulates Pten via Nedd 4 in T cells independently of its ubiquitin ligase activity. Cell Rep (2012) 1:472-82. doi:10.1016/ j.celrep.2012.04.008

108. Liu X, Karnell JL, Yin B, Zhang R, Zhang J, Li P, et al. Distinct roles for PTEN in prevention of T cell lymphoma and autoimmunity in mice. J Clin Invest (2010) 120:2497-507. doi:10.1172/JCI42382

109. Locke FL, Zha YY, Zheng Y, Driessens G, Gajewski TF. Conditional deletion of PTEN in peripheral $\mathrm{T}$ cells augments TCRmediated activation but does not abrogate CD28 dependency or prevent anergy induction. J Immunol (2013) 191:1677-85. doi:10.4049/ jimmunol.1202018

110. Li Y, Prasad A, Jia Y, Roy SG, Loison F, Mondal S, et al. Pretreatment with phosphatase and tensin homolog deleted on chromosome 10 (PTEN) inhibitor SF1670 augments the efficacy of granulocyte transfusion in a clinically relevant mouse model. Blood (2011) 117:6702-13. doi:10.1182/blood2010-09-309864

111. Rosivatz E, Matthews JG, McDonald NQ, Mulet X, Ho KK, Lossi N, et al. A small molecule inhibitor for phosphatase and tensin homologue deleted on chromosome 10 
(PTEN). ACS Chem Biol (2006) 1:780-90. doi:10.1021/cb600352f

112. Hakim S, Bertucci MC, Conduit SE, Vuong DL, Mitchell CA. Inositol polyphosphate phosphatases in human disease. Curr Top Microbiol Immunol (2012) 362:247-314. doi: 10.1007/978-94-007-5025-8_12

113. Agoulnik IU, Hodgson MC, Bowden WA, Ittmann MM. INPP4B: the new kid on the PI3K block. Oncotarget (2011) 2:321-8.

114. Fedele CG, Ooms LM, Ho M, Vieusseux J, O'Toole SA, Millar EK, et al. Inositol polyphosphate 4-phosphatase II regulates $\mathrm{PI} 3 \mathrm{~K} / \mathrm{Akt}$ signaling and is lost in human basal-like breast cancers. Proc Natl Acad Sci U S A (2010) 107:22231-6. doi:10.1073/ pnas.1015245107

115. Sasaki J, Kofuji S, Itoh R, Momiyama $\mathrm{T}$, Takayama $\mathrm{K}$, Murakami $\mathrm{H}$, et al. The Ptdins(3,4)P(2) phosphatase INPP4A is a suppressor of excitotoxic neuronal death. Nature (2010) 465:497-501. doi:10.1038/nature09023

116. Ferron M, Wei J, Yoshizawa T, Del Fattore A, DePinho RA, Teti $A$, et al. Insulin signaling in osteoblasts integrates bone remodeling and energy metabolism. Cell
(2010) 142:296-308. doi:10.1016/ j.cell.2010.06.003

Conflict of Interest Statement: William Garrow Kerr has patents pending and issues concerning the modulation and detection of SHIP activity in disease. The other authors have no conflicts to disclose.

Received: 30 June 2013; accepted: 03 September 2013; published online: 23 September 2013.

Citation: Srivastava N, Sudan $R$ and Kerr WG (2013) Role of inositol polyphosphatases and their targets in $T$ cell biology. Front. Immunol. 4:288. doi: 10.3389/fimmu.2013.00288

This article was submitted to T Cell Biology, a section of the journal Frontiers in Immunology.

Copyright (c) 2013 Srivastava, Sudan and Kerr. This is an open-access article distributed under the terms of the Creative Commons Attribution License (CC BY). The use, distribution or reproduction in other forums is permitted, provided the original author(s) or licensor are credited and that the original publication in this journal is cited, in accordance with accepted academic practice. No use, distribution or reproduction is permitted which does not comply with these terms. 